\title{
PELEMBAGAAN REFORMASI BIROKRASI DALAM KONTEKS PELAKSANAAN UU APARATUR SIPIL NEGARA DI KABUPATEN SLEMAN
}

\author{
Yanuardi $^{1}$, Utami Dewi ${ }^{2}$, dan Marita Ahdiyana ${ }^{3}$
}

\begin{abstract}
This research aims to reveal the institutionalization of bureaucratic reformation in Sleman Regency after the implementation of UU ASN. Moreover, the objective of this study is to identify the potential and inhibited factors of bureaucratic reformation in Sleman Regency. The research method of this research is descriptive by employing qualitative approach. The result of this research show that the institutionalization of bureaucratic reform after the implementation of the Act ASN in Sleman have run, and continued with a change agenda. This is evidenced by the habituation process that has been seen from the implementation of the rules and a new culture in Sleman District Government. The main obstacle was the culture of the old bureaucracy, which asked to be served, causing bureaucratic reform objectives have not been achieved optimally. In addition, the Government of Sleman regency, like other local governments in Indonesia, had to wait for the policy directives from the central government due to frequent policy changes at the central level.
\end{abstract}

Keywords: Institutionalization, Bureaucratic Reformation, UU ASN

\begin{abstract}
ABSTRAK
Penelitian ini bertujuan untuk memahami proses pelembagaan reformasi birokrasi di Pemerintah Kabupaten Sleman serta mengidentifikasi faktor-faktor pendukung dan penghambat proses pelembagaan reformasi birokrasi di Pemerintah Kabupaten Sleman. Metode penelitian yang digunakan dalam penelitian ini adalah deskriptif dengan pendekatan kualitatif. Hasil penelitian menunjukkan bahwa pelembagaan reformasi birokrasi pasca penerapan UU ASN di Kabupaten Sleman telah berjalan dan terus berlanjut dengan sejumlah agenda perubahan. Hal tersebut dibuktikan dengan telah dilaksanakannya proses pembiasaan terhadap aturan dan budaya baru yang ingin dilakukan Pemerintah Kabupaten Sleman. Kendala utama adalah budaya lama birokrasi, yang minta dilayani, menyebabkan tujuan reformasi birokrasi belum tercapai secara optimal. Selain itu, Pemerintah Kabupaten Sleman menunggu arahan kebijakan dari pemerintah pusat dikarenakan sering terjadinya perubahan kebijakan ditingkat pusat.
\end{abstract}

Kata kunci: Pelembagaan, Refomasi Birokrasi, dan UU ASN

\footnotetext{
${ }^{1}$ Dosen, Jurusan Ilmu Administrasi Negara, Universitas Negeri Yogyakarta. email: yanuardi@uny.ac.id, utami.dewi@uny.ac.id, marita_ahdiyana@uny.ac.id.
} 


\section{PENDAHULUAN}

Reformasi birokrasi sudah menjadi agenda pemerintah sejak Indonesia memasuki orde reformasi. Grand design reformasi birokrasi pun telah disusun dan terbagi dalam tiga fase mulai tahun 2010 sampai tahun 2025. Meskipun pelaksanaan desain reformasi tersebut telah berjalan lebih dari lima tahun, namun reformasi birokrasi masih belum menunjukkan hasilnya secara optimal. Kinerja para birokrat belum dianggap merepresentasikan kepentingan publik yang harus dilayani dan kepentingan negara yang harus diabdi. Banyaknya kasus korupsi, kolusi dan nepotisme menunjukkan bahwa proses reformasi birokrasi belum berhasil di Indonesia. Bahkan salah satu kriteria reformasi birokrasi yaitu pemberian pelayanan publik pun masih belum memberikan kepuasan bagi masyarakat yang berhak mendapatkan pelayanan.

Dalam rangka mempercepat proses reformasi birokrasi di tingkat daerah, Grand design reformasi birokrasi Pemerintah Indonesia 2010-2025 telah dirancang pada masa pemerintahan Presiden Susilo Bambang Yudhoyono melalui Peraturan Presiden No.81 tahun 2010 Tentang Grand Design Reformasi Birokrasi 2010-2025. Kementrian
Pendayagunaan Aparatur Negara pada masa itu mengeluarkan Keputusan No. 96 Tahun 2013 yang menunjuk 76 daerah unruk menjadi pilot project percepatan reformasi birokrasi. Daerahdaerah tersebut terdiri dari dari 33 kabupaten, 33 kota, dan 10 provinsi di Indonesia.

Salah satu daerah yang menjadi pilot project dalam mencapai tujuan di atas adalah pemerintah daerah Kabupaten Sleman. Pencanangan pelaksanaan pilot project tersebut dilaksanakan pada tanggal 31 Oktober 2013 di Aula Bappeda Sleman. Pada saat launcing Bupati Sleman Drs. Sri Purnomo, M.Si menyatakan bahwa kebijakan ini merupakan tanggung jawab Pemerintah Kabupaten Sleman untuk menjadi pelopor, role model dan garda depan dalam melaksanakan perbaikan tata laksana pelayanan publik, manajemen aparatur dan kinerja pemerintahan yang akuntabel.

Pada perkembangannya pelaksanaan reformasi birokrasi di Kabupaten Sleman harus berjalan sinergis dengan perkembangan politik dan kebijakan pemerintahan pusat. Salah satu kebijakan yang berpengaruh besar terhadap perkembangan pelaksanaan 
reformasi birokrasi di Kabupaten Sleman adalah UU No 5 Tahun 2014 tentang Aparatur Sipil Negara (ASN), yang telah merubah secara signifikan tata kelola birokrasi di Indonesia.

Pengesahan UU Nomor 5 tahun 2014 tentang Aparatur Sipil Negara yang kemudian berlaku efektif per 15 Januari 2014 menandai dimulainya babak lanjutan pembenahan birokrasi pemerintah Indonesia. Fase pertama reformasi birokrasi yang diinisiasi melalui penerbitan Perpres nomor 81 tahun 2010 tentang Grand Design Reformasi Birokrasi 2010-2025 telah berakhir pada tahun 2014. Masih ada dua fase reformasi birokrasi di depan yang masih menjadi pekerjaan rumah pemerintah hasil pemilihan umum tahun 2014 dan 2019, yaitu fase kedua (2015-2019) dan fase ketiga (2020-2024).

UU ASN dikatakan oleh para ahli menjadi tonggak sejarah reformasi birokrasi Indonesia mengingat UU ASN mengusung prinsip-prinsip New Public Management (NPM) dan mulai meninggalkan prinsip-prinsip lama model Webberian yang diusung UU Nomor 43 Tahun 1999 tentang Perubahan atas UU Nomor 8 Tahun 1974 tentang PokokPokok Kepegawaian. Dalam UU ASN tersebut penggolongan jabatan struktural dan fungsional bagi PNS diubah menjadi jabatan administrasi, jabatan fungsional, dan jabatan pimpinan tinggi. Sementara itu di luar PNS terdapat pegawai pemerintah dengan perjanjian kerja (kontrak) (Sigit Setiawan, 2014). UU ASN ini mengatur manajemen PNS yang meliputi penyusunan dan penetapan kebutuhan, pengadaan, pangkat dan jabatan, pola karier, promosi, mutasi penilaian kinerja, penggajian dan tunjangan, penghargaan, disiplin, pemberhentian, pensiun, tabungan hari tua dan perlindungan.

Setelah tiga tahun berjalan sebagai pilot project, hasil reformasi birokrasi (RB) Kabupaten Sleman belum mencapai target yang maksimal. Saat ini Kabupaten Sleman masih mendapat indeks birokrasi dengan nilai 60,97 poin, dengan nilai $\mathrm{B}$. Hasil ini menunjukkan proses RB di Kabupaten Sleman yang telah ditunjuk oleh pemerintah sebagai daerah percontohan masih menghadapi banyak hambatan dalam melakukan reformasi.

$$
\text { Agus Dwiyanto }
$$

memberikan kritik terhadap pelaksanaan reformasi birokrasi (RB) yang telah berjalan di Indonesia. Menurutnya reformasi birokrasi yang berjalan hingga saat ini sudah tidak sesuai dari jalurnya atau dari grand design reformasi birokrasi 
yang sudah dirancang. Reformasi birokrasi pada awalnya bertujuan untuk mengubah mental dan mind set Kementerian/Lembaga atau Pemda, namun demikian saat ini banyak institusi pemerintah yang lebih disibukkan dengan mengurusi hal-hal yang sifatnya dokumen. Selain itu, reformasi birokrasi yang telah berjalan juga kurang melibatkan keseluruhan stakeholders. Akibatnya, hasil reformasi birokrasi belum dapat memenuhi harapan publik. Kritik ini tentunya dapat terjadi juga di Kabupaten Sleman, namun dapat juga tidak terjadi.

Artikel ini akan mengalisis perkembangan pelembagaan reformasi birokrasi di tingkat lokal, yaitu di Kabupaten Sleman untuk melihat sejauh mana keberhasilan dan hambatan pelaksanaan reformasi birokrasi khususnya setelah diimplementasikannya UU Aparatur Sipil Negara. Kabupaten Sleman menjadi daerah yang dipilih karena Kabupaten ini telah menjadi pilot project pelaksanaan reformasi birokrasi di Indonesia pada tahun 2013.

\section{METODE}

Artikel ini dihasilkan melalui penelitian dengan pendekatan kualitatif dan analisis deskriptif karena penyajiannya berupa kata-kata tertulis maupun lisan dari orang-oarang dan perilaku yang dapat diamati. Penelitian telah dilaksanakan di lingkungan pemerintah Kabupaten Sleman yaitu pada Bagian Organisasi Pemerintah Kabupaten Sleman, Badan Kepegawaian Daerah, Sekretariat Daerah dan Badan Perencanaan Pembangunan Kabupaten Sleman. Teknik pengumpulan data menggunakan metode wawancara, observasi dan dokumentasi sementara teknik pemeriksaan keabsahan data menggunakan triangulasi sumber. Teknik analisis data menggunakan metode interaktif dari Miles dan Huberman yang meliputi pengumpulan data, reduksi data, display/penyajian data dan verifikasi serta penarikan kesimpulan.

\section{HASIL DAN PEMBAHASAN}

Proses pelembagaan reformasi birokrasi diawali dari faktor-faktor yang dipengaruhi dari luar dan dari dalam sebuah organisasi publik untuk melakukan perubahan yang dilakukan secara terencana untuk mencapai tujuan organisasi tersebut. Selanjutnya perubahan-perubahan tersebut membutuhkan upaya habitualisasi yang kemudian menngalami proses obyektifikasi dan berakhir pada proses sedimentasi. Ketika perubahan-perubahan 
yang dilakukan dalam reformasi birokrasi telah diterima dan menjadi berhasil menjadi kebiasaan-kebiasaan di organisasi, maka reformasi birokrasi sudah dapat dikatakan terlaksana. Di Kabupaten Sleman perubahanperubahanan juga dipengaruhi oleh beberapa faktor pendorong yang menyebabkan reformasi birokrasi dilakukan.

Faktor-faktor

pelaksanaan reformasi birokrasi

Reformasi Birokrasi di Kabupaten

Sleman berasal dari internal Pemerintah Kabupaten Sleman dan juga dari dorongan pemerintah pusat. Keinginan tersebut dapat ditemukan dari telah adanya semangat untuk melakukan reformasi birokrasi sebagaimana tertuang di dalam Visi misi Pemerintah Kabuapaten Sleman yang sudah diterjemahkan ke dalam Rencana Pembangunan Jangka Menengah (RPJM) 2012-2015. Keseriusan pemerintah Kabupaten Slaman ini semakin tampak ketika Pemerintah Kabupaten dalam visimisi telah menyatakan dengan jelas misi Kabupaen Sleman adalah meningkatkan tata kelola pemerintahan yang baik melalui peningkatan kualitas birokrasi dalam memberikan pelayanan prima bagi masyarakat. Dalam mencapai visi misi ini pemerintah Kabupaten Sleman Membuat Road reformasi birokrasi 2015-2019.

Sedangkan dorongan dari pemerintah pusat yang mempercepat proses pelembagaan reformasi birokrasi di Pemerintah Kabupaten Sleman terlihat dalam ditunjuknya Kabupaten Sleman oleh Kementerian Pendayagunaan Aparatur Negara sebagai salah satu dari 32 kabupaten yang menjadi pilot project pelaksanaan reformasi birokrasi. Hal tersebut termuat dalam Keputusan Menteri Pendayagunaan Aparatur Negara dan Reformasi Birokrasi Nomor 96 Tahun 2013 tentang Penetapan Pilot Project Reformasi Birokrasi pada Pemerintah Daerah. Kebijakan lain adalah dikeluarkannya UU NO 5 tahun 2014 tentang Aparatur Sipil Negara. Upayaupaya yang telah dilakukan oleh Pemkab Sleman untuk mencapai tujuan reformasi birokrasi dapat dilihat pada pembahasan program aksi.

\section{Program Aksi Pemerintah Kabupaten Sleman Dalam Pelaksanaan Reformasi Birokrasi Dalam Konteks Implementasi UU ASN}

Untuk mencapai tujuan reformasi birokrasi Pemerintah Kabupaten Sleman telah membentuk Tim reformasi birokrasi. Tim ini bertugas untuk mengawal 
pelaksanaan reformasi birokrasi yang dibentuk berdasarkan Keputusan Bupati Sleman Nomor 392/Kep.KDH/A/2013 tentang Tim Pelaksana Reformasi Birokrasi. Dalam pencapaian perubahanperubahan tersebut pemerintah Kabupaten Sleman telah menyusun, telah dan sedang melakukan 8 area perubahan sebagai langkah mencapai tujuan. Delapan are perubahan tersebut meliputi: 1) manajemen perubahan yang mencakup terbentuknya tim reformasi birokrasi, terbentuknya Roadmap Reformasi Birokasi, Evaluasi Rutin Reformasi Birokrasi, dan Perubahan Pola Pikir dan Budaya Kinerja; 2) penataan peraturan perundang-undangan; 3) penataan dan penguatan organisasi; 4) penataan tata laksana; 5) penataan sumber daya aparatur; 6) penguatan pengawasan; 7) penguatan akuntabilitas; dan 8) peningkatan kualitas pelayanan public.

Pencapain tujuan delapan area perubahan tersebut telah dilakukan secara sisematis dan terencana, sehingga perubahan-perubahan tersebut dapat tercapai. Dengan demikian di Kabupaten Sleman telah dilakukan upaya habitualiasasi terhadap perubahanperubahan baru. Namun demikian 8 Area perubahan tersebut tidak mudah dilaksanakan secara langsung, sehingga
Pemkab Sleman kemudian menerapkan manajemen perubahan sebagai bagian dari upaya mengawal perubahan yang sedang berjalan.

Sebagaimana dinyatakan diatas, manajemen perubahan dilakukan dengan membentuk tim pelaksana RB. Tim ini melakukan proses-proses monitoring dan evaluasi maupun tindak lanjut atas hasil monitoring dan evaluasi. Monitoring dan evaluasi RB dipantau setiap Selasa Pagi melalui Forum Akselerasi Kinerja Pemerintah Daerah, yang dikuatkan dengan penetapan Keputusan Bupati Sleman Nomor 27/Kep.KDH/A/2013 tentang Tim Akselerasi Kinerja Pemerintah Daerah.

Upaya lain yang dilakukan untuk melakukan perubahan adalah dengan menggerakkan Organisasi Pemerintah Daerah (OPD). Dalam mencapai tujuan tersebut maka pemerintah melalui Bagian Organisasi melakukan pembentukan agent of change ataupun role model dengan cara Pembentukan Bagian Organisasi Satgas SPIP dan Tim RB pada masing-masing OPD, yang telah ditetapkan melalui Keputusan Kepala OPD, dan dibiayai kegiatannya melalui DPA masing-masing OPD.

Dari uraian tersebut jelaslah dalam melakukan reformasi birokrasi 
dilingkungan Pemkab Sleman telah dilakukan upaya untuk mendorong agar reformasi birokrasi dapat menjadi kebiasaan (habitualisasi) di Kabupaten Sleman. Upaya yang dilakukan dengan membentuk tim pelaksana, menyusun tahap-tahapan perubahan, memonitoring dan mengevaluasi pencapaian perubahan yang dilakukan dan juga melakukan koordinasi rutin untuk memperlancar proses pelaksanaan dilapangan. Selain hal tersebut juga telah dibentuk tim-tm RB di masing-maing organisasi perangkat daerah. Setelah berjalan, pada periode kedua Pemerintahan Bupati Sri Purnomo, reformasi birokrasi tetap berlanjut. Saat ini proses pencapain tujuan reformasi birokrasi telah tersusun melalui road map, dengan tetap menyesuiakan dengan perubahan-perubahan kebijakan yang dilakukan oleh pemerintah pusat.

\section{Upaya Keberlanjutan Reformasi}

Birokrasi Pemerintah Kabupaten

Sleman

Proses reformasi birokrasi di Kabupaten Sleman telah menghasilkan banyak perubahan yang menyebabkan Pemkab Sleman mendapatkan banyak penghargaan. Evaluasi Kinerja Penyelenggaraan Pemerintah Daerah (EKPPD) yang dilakukan oleh
Kementerian Dalam Negeri atas Laporan Penyelenggaraan Pemerintahan Daerah (LPPD) Pemerintah Kabupaten Sleman adalah sebagai berikut:

1. Bidang penyelenggaraan pemerintah daerah:

a. Tahun 2012 memperoleh Peringkat 1 Nasional untuk LPPD Tahun 2011 kategori kabupaten;

b. Tahun 2013 memperoleh peringkat 8 nasional untuk LPPD Tahun 2012 kategori kabupaten, dan Bupati memperoleh penghargaan "Satyalencana Karya Bhakti Praja Nugraha" atas keberhasilan EKPPD tahun 2009-2010.

c. Tahun 2014 memperoleh "Samkarya Parasamya Purna Karya Nugraha" atas prestasi tiga tahun berturut-turut atas LPPD tahun 2011, 2012, dan 2013.

2. Pengelolaan Keuangan Derah Laporan Pertanggungjawaban Keuangan Daerah Pemerintah Kabupaten Sleman Tahun 2011, 2012, 2013, dan 2014 memperoleh Opini "Wajar Tanpa Pengecualian (WTP)" dari Badan Pemeriksa Keuangan.

3. Akuntabilitas Kinerja Pemerintahan Laporan Akuntabilitas Kinerja Instansi Pemerintah (LAKIP) Pemerintah Kabupaten Sleman Tahun 2011, 2012, 
2013 memperoleh nilai B dari Kementerian Pendayagunaan Aparatur Negara dan Reformasi Birokrasi.

4. Penyelenggaraan Pelayanan Publik

a. Pemerintah Kabupaten Sleman meraih Piala Citra Bhakti Abdi Negara Tahun 2011 dengan kategori A, dari Kementerian Pendayagunaan Aparatur Negar dan Reformasi Birokrasi.

b. Pemerintah Kabupaten Sleman melalui UPT Balai Penyuluhan Pertanian, Perikanan, dan Kehutanan, serta UPT Pelayanan Kesehatan Hewan pada Dinas Pertanian, Perikanan, dan Kehutanan, pada tahun 2013 maju ke tingkat nasional dalam Penilaian Kinerja Unit Kerja Pelayanan Publik Bidang Pertanian oleh Kementerian Pertanian dan memperoleh penghargaan Plakat "Abdibhaktitani".

c. Pemeritah Kabupaten Sleman melalui "Sarkeling" (Pasar Kerja Keliling), sebuah inovasi Bursa Kerja Online pada Dinas Tenaga Kerja dan Sosial, masuk dalam "Top 99 Inovasi Pelayanan Publik Tahun 2014" dari 515 proposal yang masuk ke Kementerian Pendayagunaan
Aparatur Negara dan Reformasi Birokrasi.

Setelah berhasil menjalankan agenda-agenda reformasi birokrasi, maka pada periode kedua pemerintahan Bupati Sri Purnomo upaya untuk pelembagaan reformasi birokrasi tetap dilaksanakan. Setelah melakukan evaluasi pemerintahan pada periode sebelumnya, maka Pemkab Sleman telah menyusun Roadmap reformasi birokrasi proses perubahan yang mengacu 8 area perubahan tetap dipertahankan dan dilanjutkan.

\section{Hambatan Pelaksanaan Reformasi} Birokrasi Pasca Implementasi UU ASN di Pemerintah Kabupaten Sleman

Dalam mencapai tujuan reformasi birokrasi, budaya adalah salah satu hambatan. Sampai saat ini budaya dominan dalam penyelenggaraan birokrasi di Indonesia adalah budaya minta dilayani. Oleh karena itu, dalam upaya menjadikan reformasi menjadi tersedimentasi (menjadi terbiasa) maka Pekab Sleman berusaha melakukan sosialisasi terus menerus. Hal tersebut sebagaiman disampaikan oleh Kepala Subbagian Ketatalaksanaan Bagian Organisasi Setda Kabupaten Sleman.

Dengan demikian, reformasi birokrasi tidak berdiri sendiri melainkan 
sudah terintegrasi dalam praktek keseharian di Kabupaten Sleman. Secara umum yang dilaksanakan terkait dengan upaya melakukan perubahan mindset pegawai. Sehingga dibutuhkan perubahan internal bagi setiap aparatur sipil negara sebagai kunci utama dalam pelaksanaan Reformasi Birokrasi. Birokrat bukanlah untuk dilayani oleh masyarakat tetapi ia berkedudukan sebagai pelayan masyarakat. Hal ini harus disampaikan melalui kegiatan sosialisasi secara terus menerus kepada para aparat sipil negara.

Namun demikian masih ditemui kendala dalam pencapaian tujuan salah satunya adalah kerumitan dalam koordinasi antara pemerintah pusat dan daerah. Karena dalam setiap perubahan yang terjadi di pusat pasti akan mempengaruhi proses-proses yang terjadi di daerah. Misalnya ketika UU ASN dilaksanakan, pemerintah daerah masih harus menunggu PP dari pemerintah pusat. Karena banyak aturan dari pemerintah pusat yang belum diatur lebih lanjut melalui Peraturan Pemerintah (PP), misalnya aturan tentang promosi jabatan.

\section{SIMPULAN}

Hasil penelitian menunjukkan bahwa reformasi birokrasi di Pemerintah Kabupaten Sleman telah mengalami proses pelembagaaan reformasi birokrasi. Hal ini dapat dibuktikan dengan telah adanya arah dan tujuan yang jelas terhadap reformasi birokrasi yang dilakukan. Hal tersebut dibuktikan dengan dilakukannya suatu upaya proses pembiasaan terhadap aturan dan budaya baru yang ingin dilakukan Pemkab Sleman. Pemkab Sleman telah membuat suatu perangkat dalam bentuk manajemen perubahan sebagai cara untuk mengawal perubahan dalam mencapai tujuannya.

Meskipun demikian masih terdapat hambatan dalam upaya menjadikan reformasi birokrasi tersedimentasi. Hal tersebut masih terlihat pada masih adanya budaya lama yang melekat pada birokrasi. Budaya birokrasi masih sebagai pihak yang dilayani, belum sebagai pelayan masyarakat. Selain itu walaupun telah ada upaya-upaya ke arah perubahan yang dilakukan oleh Pemkab Sleman, perubahan-perubahan kebijakan di tingkat pusat juga membuat daerah harus menunggu dalam melakukan perubahan. Beberapa saran yang dapat dilakukan sebagi berikut:

1. Pemerintah Kabupaten Sleman meningkatkan jalinan kerja sama secara intensif dengan beragam stakeholder terkait. Walaupun dalam mencapai pelembagaan 
reformasi birokrasi, pemerintah Kabupaten Sleman memiliki banyak pihak yang memberikan dukungan, salah satunya adalah Perguruan Tinggi.

2. Pemerintah Kabupaten Sleman melanjutkan agenda perubahan terutama dalam hal manajemen perubahan yang terkait dengan sulitnya perubahan mindset tentang pelembagaan reformasi birokrasi aparatur sipil negara.

\section{DAFTAR PUSTAKA}

Agus Pramusinto dan Agus Erwan Purwanto. 2009. Reformasi Birokrasi, Kepemimpinan dan Pelayanan Publik. Gaya Media

Eko Prasodjo dan Laode Rudita. 2014. "Undang-Undang Aparatur Sipil Negara: Membangun Profesionalisme Aparatur Sipil Negara. Jurnal Civil Service: Jurnal Kebijakan dan Manajemen PNS, Volume 8, No.1, Juni 2014 ISSN: 1978-7103

Indaru Setyo Nurprojo. 2014. "Merit System dan Politik Birokrasi di Era Otonomi Daerah". Jurnal Civil Service: Jurnal Kebijakan dan Manajemen PNS, Volume 8, No.1, Juni 2014 ISSN: 1978-7103

Husaini dkk. 2009. Metodologi penelitian. Rosdakarya
Lexy Moleong. 2007. Metodologi Penelitian Kualitatif. Bandung: PT. Remaja Penelitian). Surakarta: UNS Press

March JG, Olsen JP. 1995. Democratic Governance. The Free Press

Neo, BS. Dinamyc Governance: embedding culture, capabilities and charge in Singapore, World Scientific Publishing Co, Pte, Ltd

Rivai dkk. 2013. Kepemimpinan dan Perilaku Organisasi. Rajawali Press

Samodra Wibawa. 2004. Reformasi Administrasi. Gava Media: Yogyakarta

Sj. Sumarto, Hetifah. 2009. Inovasi, partisipasi, dan good governance: 20 prakarsa Inovatif dan partisipatiif dii Indonesia. Jakarta: Yayasan obor Indonesia.

Slamet, Y. Metode Penelitian Sosial.1998.Surakarta: Sebelas Maret University press

Sugiyono. 2010. Metode Penelitian Kuantitatif, Kualitatif, dan $R \& D$. Alfabeta: Bandung

Soesilo Zauhar. 2007. Reformasi Administrasi. Jakarta: Bumi Aksara

Tolbert Pamela S., and Zucker, Lynn G. 1996. The Institutionalization of Institutional Theory. New York: ILR Collection. 